\title{
У Syöpäpotilaiden psykososiaalinen tuki ja terveydenhuollon yhteistyö järjestöjen kanssa - erikoissairaanhoidon henkilöstön näkökulma
}

Psykososiaalinen tuki ei ole vakiintunut osaksi syöpäpotilaan hoitoa useista terveyspoliittisista linjauksista huolimatta. Tutkimuksessa analysoidaan, kenen tehtäväksi erikoissairaanhoidon syövänhoidossa toimivat terveydenhuollon ammattilaiset hahmottavat psykososiaalisen tuen antamisen, kuinka potilaiden tukemista tulisi heidän mukaansa kehittää sekä millaiseksi he ymmärtävät järjestöjen roolin tuen antajina. Aineisto kerättiin asiantuntijahaastatteluin syövänhoidossa työskenteleviltä terveydenhuollon ammattilaisilta $(n=20)$. Aineiston analyysi toteutettiin aineistolähtöisellä sisällönanalyysillä.

Syövänhoidossa työskentelevät terveydenhuollon ammattilaiset pitivät psykososiaalisen tuen antamista tärkeänä, mutta tuen antamisen katsottiiin vaativan erityistä ammattitaitoa ja nykyistä enemmän resursseja. Haastateltavien mielestä yliopistosairaalassa on vaadittavat tukipalvelut, mutta sairaalan sisällä työnjakoa ja tuen systemaattista tarjoamista tulisi kehittää. He toivoivat sairaalaan lisää henkilökuntaa, jonka työhön tuen tarjoaminen kuuluisi. Tällöin potilaiden tuen tarpeen kartoittaminen olisi automaattisesti osa diagnoosivaiheen hoitoa. Haastateltavat kuvasivat järjestöjen tarjoamaa tukea lisänä yliopistosairaalan tukipalveluihin. He korostivat, että järjestöjen tarjoaman tuen piiriin hakeutumisen tulisi perustua potilaan vapaaehtoisuuteen ja aktiivisuuteen. Haastatteluissa tuli esiin epäilyksiä järjestöyhteistyön tïvistämistä kohtaan.

Tutkimuksen tuottamaa tietoa voidaan hyödyntää kehitettäessä syöpäpotilaan kokonaisvaltaista hoitoa. Terveydenhuollon ja järjestöjen välisten raja-aitojen madaltamiseksi tarvitaan lisää tietoa järjestöjen tarjoamista tukipalveluista. Erikoissairaanhoidon henkilöstölle tarvitaan selkeämpiä ohjeita potilaiden ohjaamisesta järjestöiden palveluiden pïriin. Näiden kahden tahon välistä koulutusta syöpäpotilaan psykososiaaliseen tukemiseen liittyen tulisi lisätä. Jatkossa järjestöissä työskentelevän henkilöstön näkemyksiä erikoissairaanhoidon ja järjestöjen välisestä yhteistyöstä sekä syöpäpotilaiden psykososiaalisesta tuesta tulisi kartoittaa.

ASIASANAT: psykososiaalinen tuki, terveydenhuoltohenkilöstö, potilasjärjestöt, asiantuntijahaastattelu

EEVA HARJU, ANNASTIINA HAKULINEN, MARJAANA JONES, HANNA OJALA, ILKKA PIETILÄ 


\section{YDINASIAT}

- Erikoissairaanhoidon ammattilaisten järjestötuntemuksesta sekä ohjaamisesta järjestöjen tukitoiminnan piiriin ei tiedetä riittävästi.

- Terveydenhuollon ja järjestöjen välisten raja-aitojen madaltamiseksi tarvitaan lisää tietoa järjestöjen tarjoamista tukipalveluista, selkeämpiä ohjeita potilaiden ohjaamiseen sekä yhteistä koulutusta.

- Jatkossa tulisi tutkia järjestöjen henkilöstön näkemyksiä syöpäpotilaiden psykososiaalisesta tuesta ja yhteistyöstä erikoissairaanhoidon kanssa.

\section{TUTKIMUKSEN LÄHTÖKOHDAT}

Terveyspoliittisissa strategioissa ja ohjelmissa linjataan, että syöpähoitojen aikana tulisi kartoittaa potilaan psykososiaalista tilaa, voimavaroja sekä tuen tarpeita hoidon ja hoidon jälkeisten kuntoutustarpeiden suunnittelemiseksi. Järjestöjen tuottamat tukipalvelut, kuten vertaistoiminnan erilaiset muodot, tuodaan Sosiaali- ja terveysministeriön linjauksissa ja hallitusohjelmassa aktiivisesti esille tapoina kehittää julkisia palveluita ja parantaa asiakaslähtöisyyttä. (1-4.) Tällä hetkellä vain osa syöpään sairastuneista saa kuntoutumiseen tarvittavaa psykososiaalista tukea tai sopeutumisvalmennusta. Terveyden ja hyvinvoinnin laitos on siksi suosittanut, että sairaalaorganisaation ja sen ulkopuolisten - muun muassa KELA:n ja Syöpäjärjestöjen tuottamien - tukipalveluiden välistä yhteistyötä ja koordinaatiota tulisi parantaa. (3.) Myös neuvontapalveluiden parempi saatavuus sekä luotettavan tiedon tuottaminen syövästä edellyttävät julkisen terveydenhuollon ja järjestöjen välisen yhteistyön tiivistämistä (1).

\section{SYÖPÄPOTILAAN PSYKOSOSIAALLNEN TUKI}

Psykososiaalisella tuella on psyykkinen, sosiaalinen ja informatiivinen ulottuvuus, ja siihen voi kuulua myös vertaisen antama tuki. Tässä tutkimuksessa psykososiaalinen tuki määritellään toimiksi, joiden tarkoituksena on parantaa potilaan psyykkistä ja sosiaalista selviytymistä syöpäsairauden eri vaiheissa. (5.) Tuen antaminen vaatii vuorovaikutustaitoja ja arviota potilaan tuen tarpeesta (1, 3). Syöpään sairastuneilla on monenlaisia psykososiaalisen tuen tarpeita, jotka liittyvät tyypillisesti ahdistus-, pelko- ja kriisireak- tioihin sekä psyykkiseen kuormittuneisuuteen (3). Potilaat kaipaavat sairauden eri vaiheissa emotionaalista tukea ja mahdollisuuksia keskustella sairauden vaikutuksista omaan elämäänsä (6-8). Psykososiaalisen tuen on todettu vähentävän potilaan psyykkistä kuormitusta ja parantavan elämänlaatua (9) sekä vähentävän terveydenhuollon kustannuksia (10). Psykososiaalinen tuki ei kuitenkaan ole vakiintunut osaksi syöpäpotilaan hoitoa, vaikka tuen hyödyt tunnetaan aiempaa paremmin ja tukitarpeiden huomioimista painotetaan terveydenhuollon strategioissa (11-12). Syövänhoidossa työskentelevän henkilöstön näkökulmasta potilaiden psykososiaalisten tukitarpeiden huomioimiselle on monenlaisia sairaalaorganisaatioon, työkulttuuriin ja yksilöiden valmiuksiin liittyviä esteitä, kuten kiire, työn kuormittavuus, tukipalveluiden vähäisyys ja hoitohenkilöstön puutteelliset kyvyt tunnistaa tuen tarvetta tai antaa tukea $(11,13-15)$. Suomessa psykososiaalisen tuen tarjoamisessa on eroja sairaaloiden välillä, ja omia psykososiaalisen tuen yksiköitä toimii yksittäisissä sairaaloissa (16).

Sosiaali- ja terveysalan järjestöillä on tärkeä rooli syöpäpotilaiden psykososiaalisessa tukemisessa. Suomalainen hyvinvointiyhteiskuntamalli perustuu usean toimijan vastuisiin, ja järjestöjen toimintaa tuetaan ja rahoitetaan valtiovallan toimesta. (2.) Ei kuitenkaan ole riittävästi tietoa siitä, kuinka julkisessa terveydenhuollossa toimivat ammattilaiset tuntevat järjestöjen tukitoimintaa tai kuinka he ohjaavat potilaita ja heidän läheisiään järjestöjen toiminnan piiriin. Potilasjärjestöjen asemaa seitsemässä EU-maassa kartoittaneen pilottitutkimuksen (17) mukaan saatavilla oleva tieto potilasjärjestöjen toiminnasta on hajanaista ja terveydenhuollon ammattilaisten käsitykset potilasjärjestöjen roolista ja tehtävistä vaihtelevat. Toimintatapoja järjestöjen aseman vahvistamiseksi ei juuri ole luotu. Italialaisen tutkimuksen (18) mukaan terveydenhuollon ammattilaisten ja järjestöjen välinen yhteistyö on lisääntynyt ja osa terveydenhuollon ammattilaisista kokee potilaiden, hoitohenkilökunnan ja terveydenhuoltojärjestelmän hyötyvän tästä kehityksestä. Suhtautuminen potilasjärjestöihin ja tukiryhmiin voi kuitenkin vaihdella huomattavasti sekä ammattiryhmien sisällä että niiden välillä. Vihamielisesti tai välinpitämättömästi suhtautuvat pitävät niitä uhkana terveydenhuollon ammattimaisuudelle tai sivuuttavat niiden ole- 
massaolon. Yhteistyöhaluisesti tai osallistuvasti suhtautuvat ovat tietoisia järjestöjen toiminnasta, ohjaavat potilaita tukiryhmiin tai ovat itse mukana niiden toiminnassa.

\section{TUTKIMUKSEN TARKOITUS}

Tutkimuksen tarkoituksena on kuvata erikoissairaanhoidossa työskentelevien terveydenhuollon ammattilaisten näkemyksiä syöpäpotilaiden psykososiaalisesta tuesta ja sen antamisesta sekä järjestöjen kanssa tehtävästä yhteistyöstä. Tuotettua tietoa voidaan hyödyntää edelleen kehitettäessä syöpäpotilaan kokonaisvaltaista hoitoa.

Tässä artikkelissa tarkastellaan, miten suositukset psykososiaalisen tuen tarjoamisesta ja järjestöyhteistyöstä tällä hetkellä toteutuvat sairaalan arjessa. Tutkimuksessa etsittiin vastauksia seuraaviin kysymyksiin: 1) kenen tehtäväksi erikoissairaanhoidossa syövänhoidossa toimivat terveydenhuollon ammattilaiset hahmottavat psykososiaalisen tuen antamisen 2) kuinka potilaiden tukemista tulisi heidän näkemystensä mukaan kehittää ja 3) millaiseksi he ymmärtävät järjestöjen roolin tuen antajina.

\section{AINEISTO JA MENETELMÄT}

Tutkimuksen aineisto koostuu 20 erikoissairaanhoidossa työskentelevän terveydenhuollon ammattilaisen yksilöhaastattelusta. Haastattelut toteutettiin yliopistollisessa sairaalassa keväällä 2018 . Haastateltaviksi valittiin 10 syövänhoidon piirissä toimivaa sairaanhoitajaa, 5 lääkäriä ja 5 erityistyöntekijää, jotka työskentelivät poliklinikoilla tai vuodeosastoilla. Haastateltavista 16 oli naisia ja 4 miehiä, ja he olivat iältään 25-64-vuotiaita. Heidän työkokemuksensa syövänhoidossa vaihteli alle vuodesta yli 30 vuoteen.

Haastattelut olivat asiantuntijahaastatteluja (19). Tutkimuksessa mukana olevia haastateltiin nimenomaan heidän syövänhoidon psykososiaalisen tuen käytäntöjä koskevan tietonsa ja institutionaalisen asemansa vuoksi. Haastateltavat rekrytoitiin käyttämällä lumipallo-otantaa, jossa informanteiksi valitaan henkilöitä tutkijoiden tavoittamien avainhenkilöiden suositusten perusteella (20). Tutkijat ottivat yhteyttä syövänhoidon ylilääkäriin sekä osastonhoitajiin, jotka nimesivät mahdollisia haastateltavia. Valituille henkilöille lähetettiin tiedote tutkimuksesta ja kysyttiin sähköpostitse tai puhelimitse halukkuutta osallistua haastatteluun. Osa haastatel- tavista rekrytoitiin aikaisempien haastateltavien suositusten perusteella.

Haastattelut olivat muodoltaan puolistrukturoituja teemahaastatteluja (21). Tavoitteena oli saada monipuolisia kuvauksia tutkittavasta ilmiöstä (22). Haastattelujen kesto vaihteli noin puolesta tunnista tuntiin. Tämän artikkelin ensimmäinen ja toinen kirjoittaja toteuttivat haastattelut. Tutkimusryhmä oli laatinut haastatteluja varten teemarungon, jonka tarkoituksena oli varmistaa, että kaikkien haastateltavien kanssa käydään läpi ennalta määritetyt teemat, vaikka kysymysten muotoilu ja järjestys saattoivat vaihdella (22). Haastatteluteemoina olivat syöpäpotilaille tarjottava psykososiaalinen tuki, potilaiden ja heidän läheistensä tuen tarve ja sen tunnistaminen, järjestöjen tarjoamat tukipalvelut syöpäpotilaille sekä järjestöjen kanssa tehtävä yhteistyö.

Tutkimuksen eettisyys huomioitiin jokaisessa tutkimusprosessin vaiheessa hyvän tieteellisen käytännön edellyttämällä tavalla (23). Tutkimukseen osallistuminen perustui vapaaehtoisuuteen ja kaikille osallistujille annettiin kirjallista ja suullista informaatiota tutkimuksen tarkoituksesta ja tavoitteista. Ennen haastattelua tutkittavat saivat tietoa haastattelun luottamuksellisuudesta ja allekirjoittivat suostumuslomakkeen. Haastattelut tallennettiin tutkittavien tietoisella suostumuksella ja litteroitiin haastattelun jälkeen tekstiksi. Tutkimushankkeelle oli saatu sairaalan lupa. Tutkimukseen osallistujien anonymiteetti suojattiin ja kaikki suorat tunnistetiedot poistettiin litteroiduista materiaaleista. Tutkimusaineistojen käsittelystä, varmuuskopioinnista ja tietoturvasta huolehdittiin suunnitelmallisesti.

Aineiston analyysi toteutettiin aineistolähtöisellä sisällönanalyysilla, jossa nostettiin tutkimuskysymysten perusteella aineistosta olennainen esiin. (24-25). Sisällönanalyysissa huomio kohdistuu asiakokonaisuuksien tunnistamiseen, niiden ryhmittelyyn ja asiakokonaisuuksien välisten suhteiden hahmottamiseen. Analyysiprosessi eteni siten, että ensin litteroiduista haastatteluista poimittiin tutkimuskysymysten kannalta keskeiset kohdat, jotka olivat useamman lauseen muodostamia ajatuskokonaisuuksia. Tämän jälkeen valikoitiin erityiseen tarkasteluun niin sanotut tiheät kuvaukset. Tiheillä kuvauksilla tarkoitetaan haastattelupuheen kohtia, joissa haastateltu pohtii tutkittavaa asiaa mahdollisimman tarkasti tai 
monivivahteisesti. Seuraavassa analyysiprosessin vaiheessa tiheitä aineisto-otteita ryhmiteltiin laajemmiksi teemakokonaisuuksiksi. Samalla tuli myös näkyväksi se, millaisiin asioihin haastateltavien puhe keskittyi. Analyysin synteesivaiheessa teemakokonaisuudet tuotiin yhteen (24), ja tässä vaiheessa muodostuivat tuloksissa esitetyt kolme teemakokonaisuutta: psykososiaalinen tuki erityistyöntekijöiden työkenttänä, kiire tukemisen esteenä ja järjestöjen epäselvä rooli.

Analyysivaiheen vahvistettavuutta tuodaan esiin raportointiosiossa esitetyillä alkuperäisillä aineisto-otteilla. Anonymiteetin varmistamiseksi artikkelissa käytetyissä aineisto-otteissa näkyy vain haastateltavan ammattinimike (sairaanhoitaja, lääkäri tai erityistyöntekijä). Aineisto-otteita on tiivistetty luettavuuden parantamiseksi.

\section{TULOKSET}

Tulososa on jaettu kolmeen osaan, joista ensimmäinen käsittelee psykososiaalisiin tukitarpeisiin vastaamista. Haastatteluissa nousi selkeästi esiin ajatus siitä, että hoitojakson aikana psykososiaalisiin tukitarpeisiin vastaaminen on ensisijaisesti sairaalassa työskentelevien ammattilaisten vastuulla ja tapahtuu sairaalassa. Psykososiaalisiin tukitarpeisiin vastaaminen hahmotettiin erityistä asiantuntemusta vaativana tehtävänä, joten erityistyöntekijöillä katsottiin olevan parhaat valmiudet potilaiden tukemiseen. Toisessa osassa käsittellään haastateltavien käsityksiä psykososiaaliseen tukeen liittyvistä esteistä ja kehittämistarpeista. Haastatteluissa korostuivat ajatukset resurssien puutteesta sekä kiireestä. Vaikka näiden merkitystä ei hektisessä sairaalaympäristössä voi kiistää, vetoamalla kiireeseen haastateltavat mahdollisesti puolustivat toimintaansa ja sitä, ettei sairaalassa ole mahdollisuuksia antaa tarvittavaa tukea kaikille potilaille. Kolmanneksi nostetaan esille se, kuinka haastateltavat toivat esille järjestöjen roolin psykososiaalisen tuen tarjoajina ja hahmottivat järjestöjen ja sairaalan yhteistyötä. Järjestöjen toimintaa pidettiin yleisellä tasolla tärkeänä, mutta järjestöjen tarjoamaan tukeen ja yhteistyön lisäämiseen käytännön tasolla suhtauduttiin epäillen.

\section{PSYKOSOSIAALINEN TUKI ERITYISTYÖNTEKIJÖIDEN TYÖKENTTÄNÄ}

Kaikki haastateltavat korostivat psykososiaalisen tuen antamisen tärkeyttä ja katsoivat, että siihen tulisi panostaa syövänhoidossa nykyistä enem- män. Tuen tarve paikannettiin syöpädiagnoosin saamisen kriisivaiheeseen sekä muutosvaiheisiin, kuten hoidon vaihtumiseen ja parantavan hoidon päättymiseen. Vaikka haastateltavat kokivat omat ja kollegoidensa kyvyt tunnistaa tukitarpeita hyvinä, psykososiaalisen tuen ei kuvattu olevan osa kaikkien sairaalassa toimivien ammattilaisten jokapäiväistä työtä ja osa hoitotilanteissa tapahtuvaa kommunikaatiota. Eräs haastateltu sairaanhoitaja kuvasi omaa rooliaan psykososiaalisen tuen antamisessa seuraavasti:

K: ”Miten sä näät, ku sä kuvaat näitä eri erityistyöntekijöitä ja näitä, niin mikä se sun rooli siinä on?”

V: ”No ensinnäkin ohjata se potilas. Mä hankin heille sen avun et heidän ei tarvitse siinä kriisissään lähteä mihinkään tonne puhelinnumeroviidakkoon. Toki voin auttaa heitä niissä kaikissa lomakkeissa ja muissa, mut kyl meillä on erityistyöntekijät, jotka siihen on koulutettu, jotka tietää kaikki porsaanreiät. Lähinnä se [minulle kuuluva työ on] ohjaaminen, mistä löytyy lisäapua. Ja meillä tulee lähinnä se henkinen tukeminen, tiedon antaminen.” (Sairaanhoitaja)

Haastateltavan sanomasta käy ilmi psykososiaaliseen tukeen liittyvä ristiriita. Tuen tarpeet tunnistetaan ja "henkistä tukea" annetaan osana hoitotyötä, mutta varsinainen psykososiaalinen tuki mielletään vahvasti syövänhoidossa työskentelevien erityistyöntekijöiden osaamisalueeksi. Psykososiaalisen tuen antaminen hahmotettiin terapiakeskusteluksi, johon vaaditaan psykiatrian, kriisityön tai sosiaalityön asiantuntemusta. Ehkä juuri tästä syystä haastateltavat, jotka eivät kokeneet olevansa kyseisten alojen asiantuntijoita, kuvasivat omaa rooliaan pääasiassa tukipalveluihin ohjaajina. Myös erityistyöntekijät itse korostivat omaa asiantuntemustaan potilaiden tukemisessa ja hahmottivat potilaan ja läheisten psykososiaalisen tuen tarpeen laaja-alaisemmaksi kuin hoitajat ja lääkärit. Erityistyöntekijät nostivat esille potilaiden tukemisen arjessa selviytymisessä, kuten esimerkiksi työhön paluussa ja kertoivat omaisten tarvitsevan tukea joskus potilaan kuoleman jälkeenkin.

Haastateltavat nostivat esille tuen riittämättömyyden, mutta omien työskentely- ja toiminta- 
tapojensa muuttamisen sijaan he esittivät ratkaisuiksi erityistyöntekijöiden palkkaamista tai psykososiaalisen yksikön perustamista sairaalaan. Potilaiden tukeminen vaati heidän mielestään lisää resursseja. He kuvasivat muiden yliopistosairaaloiden ratkaisumalleja toimivimmiksi, koska niissä huomioitiin myös potilaan perhe.

”Olis hyvä että täälläki [syövänhoidossa] olis psykiatri, ainaki ees osan aikaa viikosta. Ihan konkreettisesti ottais vastaan potilaita. Ja sitten myös tähän kriisihoitoon enemmän. Että kyllä mä olisin toivonut että yliopistason sairaalassa olis psykiatrinen hoitaja, kriisityön asiantuntemusta, koulutusta.” (Erityistyöntekijä)

Potilaiden ohjaaminen saatavilla olevien tukipalveluiden piiriin näyttäytyi haastateltavien puheessa sattumanvaraisena. Haastateltavien oma suhtautuminen erikoistyöntekijöihin saattoi vaikuttaa siihen, ohjasivatko he potilaan kyseisten työntekijöiden vastaanotolle. Tukipalveluihin pääsy saattoi riippua myös potilaan omasta aloitteellisuudesta, kuten seuraavassa seksuaaliterapeutin vastaanottoa koskevassa haastatteluotteessa käy ilmi.

"Seksuaaliterapeutti on, mutta se ei oo mun agendaani kauheesti. Se ei oo jollain tavalla meikäläiselle vielä kolahtanu. Oon kuullu, että potilaat toivois että hoitajat sitä asiaa tois esille että tätä seksuaalisuuteen ja tähän liittyvää, mut mä en oo kyllä valitettavasti siihen vielä. Et kyl mä aattelen että se puoli tulis sitte sielt potilaalta." (Sairaanhoitaja)

Syöpähoitojen aikana esille nousevat psykososiaaliset tukitarpeet ja niihin vastaaminen kuvattiin haastatteluissa tärkeänä osana hoitoprosessia. Niihin haluttiin kuitenkin pyrkiä vastaamaan sairaalan sisällä, ja tuen antamisen nähtiin kuuluvan ennen muuta erityistyöntekijöiden toimenkuvaan ja osaamisalueeseen.

\section{KIIRE TUKEMISEN ESTEENÄ}

Päällimmäisenä teemana haastattelupuheessa nousi esille resurssien puute ja ennen kaikkea kiire. Aikaa potilaiden kuunteluun ja kohtaamiseen ei koettu olevan riittävästi. Haastateltavat kertoivat kiireen vuoksi keskittyvänsä kliiniseen hoitoon ja jopa välttelevänsä muista aiheista puhumista. Lyhyiden vastaanotto- ja hoitotilanteiden aikana keskitytään diagnoosin läpikäymiseen sekä hoidon suunnitteluun ja tuloksiin, eikä aikaa potilaan, saati hänen läheistensä tukemiseen koettu jäävän riittävästi.

K: ”Minkälaisena sä itse näät teidän henkilökunnan valmiuden tunnistaa näitä potilaiden tuen tarpeita?"

V: "Kyllä mun mielestä valtaosin ne on varsin hyvät. Meil on tosi hyviä kokeneita hoitajia. Lääkäreissä osa on herkempiä. Tiedostan että [meillä] on niin kauheen kiire, kauhee paine saada asioita eteenpäin. Nää keskustelut on aina semmosia et jos sulla on se puolen tunnin vastaanottoaika ja siit on minuutti jäljellä, nii jos sä siinä vaiheessa alat kysellä et, "no mites se henkinen puoli" ja "mites perhe ja mites omaiset", niin se ei oo semmonen minuutin eikä kahen keskustelu, vaa siihen pitää olla aikaa. Se on karu tosiasia. Jos on kiire niin sit on helpompi olla avaamatta sitä keskustelua, sitä laatikkoa ollenkaan, koska sitten kun sitä raottaa niin sitte pitää olla aikaa myöskin vastaanottaa se mitä sielt sit tulee. Niin tiedostan kyllä sen, että välttämättä meidän joka lääkäri ei ole kauheen altis tähän menemään.” (Lääkäri)

Haastateltavat nostivat esiin huolensa siitä, ettei tukea pystytä tällä hetkellä tarjoamaan tarpeeksi. Samalla haastateltavat kuitenkin painottivat, että hoitojen aikana psykososiaalisiin tukitarpeisiin tulisi vastata ensisijaisesti sairaalan sisällä. Kiireen helpottamiseksi toivottiin resurssien lisäämistä. Koska psykososiaalisen tuen antaminen hahmotettiin vahvasti erityisosaamisalueeksi, nousi haastatteluissa esille psykiatrisen koulutuksen saaneiden ammattilaisten palkkaaminen, kuten sairaanhoitaja seuraavassa haastatteluotteessa ehdottaa.

"No tällä hetkellä [naurahtaa] must tuntuu et ei pystytä [vastaamaan] oikeen kenenkään [tuen tarpeeseen], et meil on niin tää työtahti tiukka et tää potilaan tämmönen psykososiaalinen tukeminen ei oo meillä hallinnassa. Et kriisihoitaja on, hänellä on kolmena päivänä viikossa vastaanotto mutta se ei riitä. Ja sitten 
se että monet potilaat ei halua tulla erilliselle käynnille tänne pitkästä matkasta, et se pitäs olla helpommin saavutettavissa kaikille.” (Sairaanhoitaja)

Myös sairaalan toimintatapoja kritisoitiin, sillä rutiinien nähtiin menevän potilaiden tukemisen edelle. Jos esimerkiksi potilaalle kerrotaan ikäviä uutisia lääkärinkierrolla, ei uutisten vaikutuksia potilaaseen välttämättä huomioida, vaan kierto jatkuu aikataulun mukaisesti. Vaikka henkilökunta kokisi velvollisuudekseen olla läsnä ja tukea potilasta, ei heillä ole siihen aikaa. Toisaalta kiireeseen vetoaminen antoi myös mahdollisuuden olla keskustelematta vaikeista asioista potilaan kanssa. Osa haastateltavista kertoi suoraan tuntevansa epävarmuutta siitä, kuinka potilaita tai läheisiä voisi tukea emotionaalisesti tai psyykkisesti. Kliiniseen hoitoon keskittyminen saattoi siksi tuntua turvallisemmalta kuin tunteista puhuminen. Seuraavassa otteessa sairaanhoitaja korostaa henkilökunnan hyviä valmiuksia tunnistaa tuen tarvetta, mutta samalla hän toteaa pääsevänsä helpommalla keskittyessään puhumaan vain lääkehoidosta. Toisaalta hän perustelee kliiniseen hoitoon keskittymistä myös sillä, että se tukee potilaan jaksamista.

K: "Minkälaisena sä näät henkilökunnan valmiudet tunnistaa potilaiden tuen tarpeita täällä?”

V: "No mä näkisin et valmiudet on kyllä ihan hyvät mut siihen ei oo aikaa. Ku on se että, esimerkiks jos sytostaattipuolellakin ottaa puheeks sen, jotenkin jo istahdat sinne vielä ja oot sen näkönen et nyt mä annan sulle tätä aikaa ja nyt puhutaan mitä kuuluu ja, annetaan tilaa ilmetä kaikenmoisille tunteille ni sit tietää et jos mul on ne seittemän muutaki potilasta tuolla tänään nii mul ei olis tähän aikaa, et sillon helpommalla pääsee hoitaja itte kun ei kysy mitään, et hoidetaan tää sytostaattiasia kysytään nopeesti vaan voinnista ja se kirjataan ja sitte "moikka, seuraavaan kertaan". Se monessa kohtaa ehkä tukee toisaalta potilaan jaksamistaki et se on vähä semmonen piiska takapuolelle et nyt tää hoito ja sitte mennään ja nyt ollaan tällä systeemillä tässä, reippaasti liikentees ja tää juna vie hoidot loppuun asti ja sitte sä oot seurannassa. Siin on hyviäki puolia, mut siit jää kyllä se semmonen kuuntelu ja voi olla et potilaat välillä kokee että, just tää et ei häneltä oo kukaan kysyny mitä hänelle oikeesti kuuluu tai mitä hänen läheisille kuuluu.” (Sairaanhoitaja)

Haastateltavat toivoivat moniammatillisen yhteistyön lisäämistä sairaalassa työskentelevien ammattiryhmien välillä. He korostivat, että psykososiaalisen tuen tarve tulisi kartoittaa rutiiniomaisesti jokaisen syöpään sairastuneen kohdalla. Näin taattaisiin, että kaikilla potilailla olisi mahdollisuus saada tarvitsemaansa tukea. Hoidon katsottiin kuitenkin painottuvan pääsääntöisesti somaattiseen puoleen, jolloin psykososiaalisen tuen antaminen potilaille riippuu hoitavasta henkilöstä. Vastauksena tähän esitettiin uusien toimintatapojen luomista, jolloin tukea tarjottaisiin diagnoosivaiheessa automaattisesti. Toisaalta, vaikka haastatteluissa painotettiin ammattilaisten yhteistyötä ja tuen tarjoamista jokaiselle, nousi haastattelupuheessa esille vaihtelevia asenteita psykososiaalista tukea ja yhteistyötä kohtaan. Pitkään syövänhoidossa työskennelleet haastateltavat saattoivat verrata tilannetta aiempiin vuosikymmeniin ja todeta, että nykyiset tukipalvelut olivat riittäviä. He painottivat potilaiden omaa aktiivisuutta ja vapaaehtoisuutta muistuttaen, että kaikki potilaat eivät myöskään tarvitse tai halua tukea.

Haastatteluissa kuvattiin kehittämistarpeita ja esteitä potilaiden tukemiselle, joista päällimmäisinä olivat kiire, resurssien vähäisyys, moniammatillisen yhteistyön puute ja se, ettei tuen tarjoamista ole liitetty osaksi hoitopolkua. Kehittämisestä puhuttaessa ei kuitenkaan juuri nostettu esille tarvetta kehittää omaa osaamista tai muuttaa henkilökohtaisia työtapoja, vaan vastausta ongelmiin haettiin pikemminkin uusien erityistyöntekijöiden palkkauksesta. Myös potilailta toivottiin lisää oma-aloitteisuutta tuen hakemisessa. Kiire on osa sairaalan arkea, mutta vetoamalla kiireeseen haastateltavat pystyivät osaksi peittelemään omaa epävarmuuttaan siitä, kuinka kohdata ja käsitellä potilaan tunteita. Haastateltavat korostivat sitä, että sairaalassa ei tällä hetkellä pystytä vastaamaan potilaiden kaikkiin tukitarpeisiin. Tästä huolimatta haastateltavat eivät juurikaan nostaneet esiin sairaalan ulkopuolella toimivia tukipalveluja. Haastatteluissa järjestöt kuvattiin tärkeinä yhteistyökump- 
paneina, mutta haastateltavat eivät välttämättä spontaanisti tuoneet ilmi järjestöjen asemaa tai mahdollisuutta tukea potilaita hoitojen aikana. Seuraavassa osassa käsittelemme terveydenhuollon ja järjestöjen suhdetta lähemmin ja keskitymme erityisesti siihen, millaisena järjestöjen rooli hahmotetaan potilaiden tukemisessa.

\section{JÄRJESTÖJEN EPÄSELVÄ ROOLI}

Vaikka sairaalan tarjoamat tukipalvelut nähtiin puutteellisina, harva haastateltava nimesi järjestötoimijoita tai vertaistukiryhmiä syöpäpotilaan psykososiaalisen tuen antajiksi. Järjestöjen asema kuvattiin aktiivihoitojen aikana jopa tarpeettomana, ja tuen hakeminen sairaalan ulkopuolelta nähtiin potilasta kuormittavana.

\section{K: ”Siellä [paikallisessa syöpäyhdistyksessä] toimii myös näitä neuvontahoitajia, niin min- kälainen sä ajattelisit että olis heidän rooli tässä syöpäpotilaiden tukemisessa?”}

V: ”Mä aattelen et jos potilas on jo meillä kirjoilla, tulee tänne, niin en mä tiedä sitten onko siinä Syöpäyhdistyksen hoitajalla tarvetta, taikka ainaki mä jossain määrin aattelen viel jopa niinkin, että ei kuuluiskaan ehkä olla, ku se potilas on meijän hoidossa, niin sillon meijän täytyis saada se kaikki palvelu sille potilaalle parhaalla mahollisella tavalla, ettei hänen tarvis lähtee enää sen asian takia. Toki sitte ku siirrytään seurantoihin ja pitempiin, jos tulee semmonen pitemmät seurantakaaviot sun muuta niin sitten sinne väliaikaan mutta, näin mä näkisin, että se on meijän tehtävä tässä kohtaa koska potilas on meidän potilas. Et siinä kohtaa ei sitten ihan välttämättä tarvita ulkopuolista hoitajaa.” (Sairaanhoitaja)

Haastateltavat kuvasivat suhtautuvansa järjestöihin ja järjestöjen kanssa tehtävän yhteistyön lisäämiseen myönteisesti, kun heiltä kysyttiin asiasta. He nostivat kuitenkin esille myös epäilyksiä järjestöissä toimivien henkilöiden osaamista kohtaan ja korostivat koulutuksen ja ammattitaidon merkitystä syöpäpotilaiden tukemisessa. Järjestöistä puhuttaessa haastateltavat mainitsivat erityisesti vapaaehtoistoimijoiden mahdollisen tiedon ja ammattitaidon puutteen. Samanlaisia asioita korostettiin myös keskusteltaessa järjestöissä toimivista neuvontahoitajista. Seuraavassa otteessa haastateltava tuo taas esille ajatuksen siitä, että psykososiaalisiin tukitarpeisiin voi vastata ainoastaan potilaan sairaalahoidossa mukana oleva ammattilainen. Kysyttäessä järjestöyhteistyön mahdollisista negatiivisista seurauksista hän toteaa, että järjestöjen kautta voitaisiin jakaa potilaille väärää tietoa.

”No jotkut ehkä ajattelee sit näitä huonoja asioita että "ne vie meijän työt" mutta mä en usko siihen koska me ollaan niin eri alueella. Mutta jotkut voi kokea sillä lailla. Ja sitten huonoo se että jos he ei tiedä näistä meijän uusista hoidoista niin sitten he antaa väärää tietoo, niin se on se oleellinen. Ja onhan sieltä joku ollu täällä opissa en mä sitä sano mutta vois kaikkikin käydä, koska sinnekin kun tulee uusi niin ei se tiä meijän toiminnasta jos ei se oo sairaalassa ollu." (Sairaanhoitaja)

Ehdotuksena yhteistyön vahvistamiseksi esitettiin järjestöjen ylläpitämän potilastietopisteen avaamista sairaalaan. Järjestötoimijoiden tai vapaaehtoisten vertaistukihenkilöiden läsnäoloon sairaalassa ei kuitenkaan suhtauduttu varauksettomasti. Järjestöjen organisoiman vertaistuen tarpeellisuutta ei muutenkaan juuri tuotu esiin haastatteluissa, sillä haastateltavat korostivat potilaiden saavan vertaistukea hoitojen aikana toisiltaan tai vaikkapa internetin keskusteluryhmistä. Seuraavassa otteessa haastateltavalta on kysytty näkemyksiä potilastukipisteestä ja vertaistuen näkyvämmästä roolista sairaalassa.

"Miksei se vois olla mahdollista. Mut että siinä tullaan juuri siihen kysymykseen siihen sanaan koulutus. Ne täytyy olla hyvin koulutettuja, hyvin mietitty ne ihmiset persoonina et ne sopii tänne Että en uskaltais ihan ketä tahansa päästää syöpäpotilaan vuoteen äärelle. Ja mun mielest se on, sen potilaan arvostamista. Yhtään aliarvioimatta sitä jota en sinne halua päästää. Hänel on lahjat joihinkin muihin asioihin elämässä, ei välttämättä tähän. Mun mielest on upeeta että esimerkiks joku hoitaja sanoo että minä en siellä syöpäosastolla jaksais toimia että minä oon enemmän tuolla [ensiavussa], mun persoonani sopii sinne. Sehän on oikeaa itsetuntemusta. Mutta tollaseen vertaistukitoimintaankin saattaa hakeutuu ihmisii joilla ei itsetuntemus oo niin 
vahva. Ja he ei näe sitä että he ei ehkä oo, parhaita mahdollisii toimijoita siellä sairaalassa. Et se on aina että vapaaehtonen toimii tämmöses ympäristössä ni se on aika iso ja mun mielest se on erittäin iso haaste. Et kyl se hyvin tarkkaan täytyy luoda se organisaatio ja, se järjestelmä, miettiä tosi monen, ammattilaisesti, että onko tää järkevää.” (Erityistyöntekijä)

Kun haastateltavilta kysyttiin heidän järjestötuntemuksestaan sekä yhteistyökokemuksistaan, vastaukseksi mainittiin paikallinen syöpäyhdistys. Yhteistyöstä yhdistysten kanssa puhuttiin hyvin yleisellä tasolla. Tärkein konkreettinen esimerkki oli, että Syöpäyhdistys on mukana uusille syöpäpotilaille tarkoitetussa ensitietopäivässä. Järjestöjen tuottamaa kirjallista materiaalia saatettiin antaa potilaille tai pitää esillä odotustiloissa, joista potilaat pystyivät niitä itse ottamaan. Jokainen kertoi ohjaavansa potilaita ja heidän läheisiään järjestöjen toimintaan omalla tavallaan; osa järjestelmällisemmin, osa satunnaisemmin, osa ei lainkaan. Toimintayksiköissä ei ollut olemassa yhdessä sovittua ohjeistusta ohjata potilaita ja heidän läheisiään järjestöjen toimintaan, mutta yksiköissä saattoi olla nimettyjä hoitajia, jotka toimivat yhdyshenkilöinä järjestöjen suuntaan. Haastateltavien järjestötuntemus oli pitkälti jokaisen oman aktiivisuuden ja mielenkiinnon varassa ja perustui henkilökohtaisiin tuttavuuksiin järjestötoimijoiden kanssa. Haastateltavat olivat saattaneet työskennelleet Syöpäyhdistyksellä työuransa aikana. Järjestöyhteistyö ja toiminnasta tiedottaminen kuvattiin hoitajan työhön kuuluvaksi. Erityisesti lääkärit luottivat siihen, että hoitajat kertovat potilaalle järjestöistä ja niiden tarjoamista palveluista. Haastatteluissa ehdotettiin yhteistyön tiivistämistä järjestöjen kanssa, mutta sen toivottiin tapahtuvan järjestöjen aloitteesta.

K: ”No minkälainen rooli sun mielestä järjestöillä pitäis ylipäätään olla tässä [sairaalan] toiminnassa?"

V: ”Mä nään, että [paikallinen syöpäyhdistys] toimii aika hyvinki, että kyllähän se rooli on siihen jälkihoitoon juuri siihen mihin, kun täällä se päättyy.. Mutta se että se menis sitten kaikkien ihmisten tietoon, varmasti.. Niin se varmaan semmonen tiedotus pitäis olla vielä parempaa. Voisko se rooli olla jopa ihan niin iso et tääl ois joku piste missä he, vaikka päivystäis, aina. Jos nyt ajattelee että, tääl on kuitenki erityistyöntekijöitä aika hyvinki tarjolla että, jos se, yhteistyö toimis täällä saumattomasti niin sit välttämättä ei tarvis ees Syöpäyhdistyksen rooli tässä sairaalassa olla niin iso. Että kun tääl on kuitenki työntekijöitä jotka pystyy, myöski aika monenlaisia asioita tekemään, et sitte se ehkä on hyvä et täällä sairaalassa on tietyt ja sitte sairaalan jälkeen on se tietty apu tarjolla.” (Erityistyöntekijä)

Kuten edellisestä otteesta käy ilmi, järjestöjen työn hahmotettiin alkavan vasta hoitojen päättymisen jälkeen. Aktiivihoitojen aikana järjestöjä ei nähty potilaan psykososiaalisen tuen antajina, ja yhteistyön tiivistämiseen liitettiin uhkakuvia. Järjestöjen kanssa tehtävän yhteistyön kehittämisen sijaan tai rinnalla monet haastateltavat toivoivat sairaalan omien tukipalveluiden kehittämistä ja erityistyöntekijöiden välisen yhteistyön lisäämistä.

\section{POHDINTA}

Tutkimus osoittaa, että kaikki syövänhoidossa työskentelevät terveydenhuollon ammattilaiset eivät katso psykososiaalisen tuen kuuluvan olennaisena osana heidän työhönsä. Haastateltavat pitivät psykososiaalista tukea tärkeänä asiana, mutta katsoivat tuen antamisen vaativan erityistä ammattitaitoa ja nykyistä enemmän resursseja. Yliopistosairaalassa eri ammattiryhmillä on omat, tarkkaan rajatut erikoisosaamisalueensa, joiden kautta sairaalan sisäinen työnjako on organisoitu. Erikoistuminen voi johtaa eri ammattiryhmien välisten työnjakoa ja osaamista koskevien rajojen tarkkaan seuraamiseen, jolloin potilaan hoidossa mietitään jatkuvasti, kenelle hoidon eri osa-alueet kuuluvat. Samalla ammattiryhmät suojelevat omaa professiotaan ja voivat rajata ei-toivottuja työtehtäviä oman työnsä ulkopuolelle. (26.) Aiemmista tutkimuksista $(27,28)$ käy ilmi, että myös järjestöissä toimivat vertaistukihenkilöt ovat tietoisia erikoistumisen vaateesta ja tuovat esiin osaamistaan erikoistumisen näkökulmasta.

Syövänhoito yhtenä yliopistosairaalan erikoisalana keskittyy pitkälti syövän somaattiseen 
hoitoon. Tässä ympäristössä psykososiaalinen tuki voidaan hahmottaa uutena ja vielä kehittymättömänä osana hoitoa, joka ei tällä hetkellä kuulu selkeästi minkään sairaalassa työskentelevän ammattiryhmän vastuulle. Tämä voi osaltaan selittää sitä, miksi haastateltavat eivät hahmottaneet psykososiaalisen tuen antamista osaksi omaa työtään vaan korostivat sen vaativan erikoistunutta osaamista. Haastateltavien mukaan sairaalassa ei ole selkeitä ja vakiintuneita toimintatapoja siihen, kuinka potilaita ohjataan tukipalveluihin. Myös aiemmassa tutkimuksessa (13) on havaittu, että epäselvät toimintakäytännöt ja erityistyöntekijöiden huono saatavuus ovat terveydenhuollon henkilöstön mukaan esteitä potilaiden tukemiselle.

Kehittämistarpeet nähtiin oman työn muuttamisen sijaan sairaalan resursseihin ja toimintakäytäntöihin liittyvänä kysymyksenä. Haastateltavat katsoivat, että yliopistosairaalassa on lähtökohtaisesti olemassa vaadittavat tukipalvelut, mutta sairaalan sisällä työnjakoa ja tuen systemaattista tarjoamista tulisi kehittää. Psykososiaalinen tuki tulisi liittää osaksi tietyn ammattiryhmän tai -ryhmien erikoisosaamista, ja näille toimijoille tulisi sairaalan sisällä suunnata enemmän resursseja. Haastateltavat toivoivat, että potilaiden tuen tarpeen kartoittaminen olisi automaattisesti osa diagnoosivaiheen hoitoa. Tämä on ristiriidassa yksilöllisen hoidon kanssa ja jättää huomiotta sen, että tarvittava tuen määrä ja tuen tarpeen ajankohta vaihtelevat eri potilailla. Aiempien tutkimusten $(6,29)$ mukaan läheiset ja puolisot ovat potilaalle merkittäviä tukijoita, jotka kuitenkin tarvitsevat myös itse tukea. Tätä näkökulmaa haastateltavat eivät juuri tuoneet esille. Tämä korostaa myös näkemystä siitä, että psykososiaalinen tukeminen on tietyn ammatillisen koulutuksen saaneen henkilön tehtävä eikä osa jokapäiväistä elämää.

Ammattiryhmien väliset reviirirajat ja kapean sektorin osaamisen korostaminen potilaan hoidossa ovat ristiriidassa sellaisten terveyspoliittisten tavoitteiden kanssa, joiden pyrkimyksenä on madaltaa terveydenhuollon sektoreiden sekä terveydenhuollon ja järjestöjen välisiä raja-aitoja. Syövänhoidon kehittämisessä korostuu erikoissairaanhoidon ja yliopistosairaaloiden rooli (30), eikä järjestöjen asemaa juurikaan huomioida. Samaan aikaan terveyspoliittisessa päätöksen- teossa korostetaan terveyspalvelujen integraatiota, jonka kautta pyritään vastaamaan potilaiden monimuotoisiin tarpeisiin erikoissairaanhoidon, perusterveydenhuollon ja järjestötoimijoiden tiiviimmällä yhteistyöllä (2). Suomessa on laaja syöpä- ja potilasjärjestökenttä, joka tarjoaa potilaille sekä heidän läheisilleen tietoa sekä mahdollisuuksia vertaistukeen ja keskusteluihin neuvontahoitajien kanssa. Haastateltavat kuvasivat järjestöjen tarjoamaa tukea lisänä yliopistosairaalan tukipalveluihin, mutta he korostivat, että järjestöjen tarjoaman tuen piiriin hakeutumisen tulisi perustua potilaan vapaaehtoisuuteen ja aktiivisuuteen. Haastatteluissa esitettiin monenlaisia epäilyksiä järjestöyhteistyön tiivistämistä kohtaan. Osa haastateltavista kuvasi järjestöissä toimivien henkilöiden puutteellisen osaamisen vaarantavan yliopistosairaalan asiantuntemukseen perustuvan hoidon. Varauksellinen suhtautuminen yhteistyöhön voi liittyä siihen, ettei järjestöjen toimintaa tunneta riittävästi (18). Toisaalta erikoissairaanhoidon eri erikoisalojen tarkkarajaisuus on jo lähtökohtaisesti ristiriidassa eri toimijatahojen yhteistyötä korostavien terveyspoliittisten tavoitteiden kanssa.

Aineisto kerättiin yliopistollisessa sairaalassa, eivätkä esitetyt tulokset välttämättä kuvaa tilannetta muunlaisissa organisaatioissa. Haastateltavat edustivat kuitenkin laaja-alaisesti eri ammatti- ja ikäryhmiä sekä syövänhoidon erikoisalueita ja toimintayksiköitä. Otannan valikoituminen on yksi lumipallomenetelmän heikkous (31). Toisaalta tutkimuksen reflektiivisyyttä vahvistaa se, että koko tutkimusryhmä osallistui haastattelujen suunnitteluun ja analyysiprosessin etenemiseen. Ensimmäisellä kirjoittajalla oli työkokemusta syöpäpotilaiden hoitamisesta, mutta asiantuntijatiedon olemassaolosta ja mahdollisista vaikutuksista aineiston tulkintaan ja haastattelutilanteissa toimimiseen pyrittiin olemaan mahdollisimman tietoisia. $(22,31$.)

Tulosten perusteella voidaan esittää, että syöpäpotilaiden psykososiaalisen tuen kehittäminen edellyttää olemassa olevien toimintakäytäntöjen selkeyttämistä. Lisäksi tulisi parantaa syövänhoidossa työskentelevien ammattiryhmien kykyä tunnistaamahdollisuuksiaantarjotatukeaosanapotilaiden kohtaamista. Terveydenhuollon ja järjestöjen välisten raja-aitojen madaltamiseksi tarvitaan 1) lisää tietoa järjestöjen tarjoamista tuki- 
palveluista, 2) terveydenhuollon henkilöstölle selkeämpiä ohjeita potilaiden ohjaamisesta järjestöiden palveluiden piiriin sekä 3) yhteistä koulutusta syöpäpotilaan psykososiaaliseen tukemiseen liittyen. Jatkossa myös järjestöjen henkilöstön näkemyksiä syöpäpotilaiden psykososiaalisesta tuesta ja yhteistyöstä julkisen terveydenhuollon kanssa tulisi tutkia.

\section{RAHOITTAJAT:}

Tämä tutkimus on osittain rahoitettu yhden yliopistollisen sairaalan erityisvastuualueen kilpailutettavalla valtion tutkimusrahoituksella.
KIRJOITTAJIEN KONTRIBUUTIOT:

Harju on osallistunut tutkimuksen suunnitteluun, vastannut tutkimuksen toteutuksesta, analyysistä ja artikkelikäsikirjotuksen kirjoittamisesta. Hakulinen on osallistunut tutkimuksen suunnitteluun, vastannut tutkimuksen toteutuksesta, analyysistä ja artikkelikäsikirjotuksen kirjoittamisesta. Jones on osallistunut tutkimuksen suunnitteluun, analyysiin ja artikkelikäsikirjoituksen kirjoittamiseen. Ojala on vastannut tutkimuksen suunnittelusta, osallistunut tutkimuksen analyysin ja artikkelikäsikirjoituksen kirjoittamiseen ja kommentointiin. Pietilä on vastannut tutkimuksen suunnittelusta, osallistunut tutkimuksen analyysin ja artikkelikäsikirjoituksen kirjoittamiseen ja kommentointiin.

\section{Harju, E., Hakulinen, A., Jones, M., Ojala, H., Pietilä, I. Psychosocial support for cancer patients and collaboration with patient organisations - the perspective of specialist healthcare personnel. Sosiaalilääketieteellinen aikakauslehti - Journal of Social Medicine 2019: 56: 192-203.}

Despite health policies highlighting the significance of psychosocial support in cancer care, it has not become an established part of the treatment of carer patients. This study, focuses on the issue of psychosocial support provision from the perspective of health professionals working in specialist cancer services and asks who should provide psychosocial support, how support provision should be developed and how professionals view the role of voluntary sector patient and cancer organisations in this process. Materials consist of expert interviews with health professionals $(n=20)$ working in cancer care. The interviews have been analysed using content analysis.

Although the professionals regarded psychosocial support as important, they considered the provision of support to require specialist expertise and more resources. The interviewees expressed that currently the hospital has the necessary means to offer support to cancer patients but these resources should be strengthened by clarifying the duties associated with different professional groups and by offering support more systematically. They also called for an increase in the number of professionals specialised in psychosocial care. The interviewees described the services offered by voluntary sector organi- sations as supplementary to those offered by the university hospital. They emphasised that seeking these services should be voluntary and rely on the patient's own activeness. The professionals expressed doubts about increasing collaboration with the organisations.

The information produced by this study can be utilised to develop the holistic treatment of cancer patients. In order to reduce the barriers between specialist health services and voluntary sector organisations, health professionals need to be provided with more information regarding the work of patient and cancer organisations. There should also be clearer instructions for health professionals to direct patients to support services and joint training on issues related to psychosocial support that could bring together personnel from both sectors. In the future, it is important to explore the perspectives of voluntary sector personnel on collaboration with specialist cancer services and on the psychosocial support needs of patients.

Keywords: psychosocial support, healthcare personnel, patient organisations, specialist interview

Saapunut 30.10.2018

Hyväksytty 02.03.2019 
(1) Sosiaali- ja terveysministeriö. Syövän hoidon kehittämien vuosina 2010-2020. Työryhmän raportti. Sosiaali- ja terveysministeriön selvityksiä 2010:6. Luettu 28.8.2018. http://urn.fi/URN:ISBN:978-952-00-2971-5

(2) Sosiaali- ja terveysministeriö. Sosiaali- ja terveysalan kansalaisjärjestöt sosiaali- ja terveysministeriön kumppaneina. Sosiaali- ja terveysministeriön järjestöpoliittiset linjaukset 2011. Luettu 11.9.2018. http://urn.fi/ URN:ISBN:978-952-00-3161-9

(3) THL:n syöpätautien asiantuntijaryhmä. Syövän ehkäisyn, varhaisen toteamisen ja kuntoutumisen tuen kehittäminen vuosina 2014-2025. Kansallisen syöpäsuunnitelman II osa. Terveyden ja hyvinvoinnin laitos (THL). Ohjaus 6/2014. Luettu 1.9.2018. http://urn.fi/ URN:ISBN:978-952-302-185-3

(4) Valtioneuvoston kanslia. Ratkaisujen Suomi. Pääministeri Juha Sipilän hallituksen strateginen ohjelma 29.5.2015. Hallituksen julkaisusarja 10/2015. Luettu 26.8.2018. https:// valtioneuvosto.fi/documents/10184/1427398/ Ratkaisujen+Suomi_FI_YHDISTETTY_netti.pdf

(5) Galway K, Black A, Cantwell M, ym. Psychosocial interventions to improve quality of life and emotional wellbeing for recently diagnosed cancer patients. Cochrane Database Syst Rev 2012;11:1 771. Art.No.:CD007064. doi.org/10.1002/14651858.CD007064.pub2

(6) Dieperink K, Coyne E, Creedy DK, ym. Family functioning and perceived support from nurses during cancer treatment among Danish and Australian patients and their families. J Clin Nurs 2018;27:e154-e161. doi:10.1111/jocn.13894

(7) Lehto US, Helander S, Taari K, ym. Patient experiences at diagnosis and psychological well-being in prostate cancer: A Finnish national survey. Eur J Oncol Nurs 2015;19:220-229. doi: 10.1016/j.ejon.2014.10.018

(8) Schumacher JR, Palta M, Loconte NK, ym. Characterizing the psychological distress response before and after a cancer diagnosis. J Behav Med 2013;36:591-600. doi: 10.1007/s10865-012-9453-x

(9) Faller H, Schuler M, Richard M, ym. Effects of psycho-oncologic interventions on emotional distress and quality of life in adult patients with cancer: Systematic review and meta-analysis. J Clin Oncol 2013;31:782-793. doi: 10.1200/JCO.2011.40.8922

(10) Carlson LE, Bultz BD. Benefits of psychosocial oncology care: Improved quality of life and medical cost offset. Health Qual Life Outcomes 2003;1:8. doi:10.1186/1477-7525-1-8

(11) Dilworth S, Higgins I, Parker V, ym. Patient and health professional's perceived barriers to the delivery of psychosocial care to adults with cancer: a systematic review. Psychooncology 2014;23:601-612. doi: $10.1002 /$ pon.3474
(12) Grassi L, Spiegel D, Riba M. Advancing psychosocial care in cancer patients. F1000Research 2017;6:2083. doi: 10.12688/f1000research.11902.1

(13) Absolom K, Holch P, Pini S, ym. The detection and management of emotional distress in cancer patients: the views of health-care professionals. Psychooncology 2011;20:601-608. doi: 10.1002/pon.1916

(14) Aldaz BE, Treharne GJ, Knight RG, ym. Oncology healthcare professionals' perspectives on the psychosocial support needs of cancer patients during oncology treatment. J Health Psychol 2016;22:1332-1344. doi: 10.1177/1359105315626999

(15) Fagerlind H, Kettis A, Glimelius B, ym. Barriers against psychosocial communication: oncologists' perceptions. J.Clin Oncol 2013;31:3815-22. doi: 10.1200/JCO.2012.45.1609

(16) HUS. Psykososiaalinen tuki. Luettu 30.10.2018 http://www.hus.fi/sairaanhoito/ sairaanhoitopalvelut/syopataudit/tuki_ja_ hyvinvointi/Sivut/Psykososiaalinen-tuki.aspx

(17) Keizer B, Bless R. Pilot study on the position of health consumer and patients' organisations in seven EU countries. 2010. Luettu 30.10.2018. http://www.pharos.nl/documents/doc/pilot study_on_the_position_of_health_consumer_-_ patients_organisations.pdf

(18) Pavolini E, Spina E. Users' involvement in the Italian NHS: the role of associations and self-help groups. J Health Organ Manag 2015;29:570-581. doi:10.1108/JHOM-05-2014-0089

(19) Alastalo M, Åkerman M, Vaittinen T. Asiantuntijahaastattelu. Kirjassa: Hyvärinen M, Nikander P, Ruusuvuori J. (toim.) Tutkimushaastattelun käsikirja. Tampere: Vastapaino;2017, 214-232.

(20) Saaranen-Kauppinen A, Puusniekka A. KvaliMOTV - Menetelmäopetuksen tietovaranto [verkkojulkaisu]. Tampere: Yhteiskuntatieteellinen tietoarkisto 2006. Luettu 24.5.2018. http://www.fsd.uta.fi/ menetelmaopetus/

(21) Hirsjärvi S, Hurme H. Tutkimushaastattelu. Teemahaastattelun teoria ja käytäntö. (muuttumaton lisäpainos) Helsinki: Gaudeamus; 2011.

(22) Kylmä J, Juvakka T. Laadullinen terveystutkimus. 1.-2. painos. Helsinki: Edita Publishing Oy; 2012.

(23) TENK. Hyvä tieteellinen käytäntö ja sen loukkausten käsitteleminen Suomessa. PDFjulkaisu. 2012. Luettu 24.2.2019. http://www.tenk.fi/fi/ohjeet-ja-julkaisut

(24) Tuomi J, Sarajärvi A. Laadullinen tutkimus ja sisällönanalyysi. EU: Kustannusosakeyhtiö Tammi; 2018. 
(25) Laine T. Miten kokemusta voidaan tutkia? Fenomenologinen näkökulma. Kirjassa: Valli R. (toim.) Ikkunoita tutkimusmetodeihin 2. Näkökulmia aloittelevalle tutkijalle tutkimuksen teoreettisiin lähtökohtiin ja analyysimenetelmiin. Keuruu: Otavan Kirjapaino; 2018.

(26) Nancarrow SA, Borthwick AM. Dynamic professional boundaries in the healthcare workforce. Sociol Heatlh Ill 2005;27:897-919. doi.org/10.1111/j.1467-9566.2005.00463.x

(27) Jones M, Pietilä I. Expertise, advocacy and activism: A qualitative study on the activities of prostate cancer peer support workers. Health 2018. doi:10.1177/1363459318785711

(28) Pietilä I, Ojala H, Helminen S, ym. Eturauhassyövän tukihenkilö - vertainen vai asiantuntija? Sosiaalilääk Aikak 2014;51:101112.

(29) Harju E, Rantanen A, Kaunonen M, ym. Marital relationship and health-related quality of life of patients with prostate cancer and their spouses: a longitudinal clinical study. J Clin Nurs 2018;27:2633-2639. doi: 10.1111/jocn.14343

(30) Sosiaali- ja terveysministeriö. Syöpäkeskus. Luettu 22.10.2018. https://stm.fi/syopakeskus

(31) Polit D, Beck C. Nursing research: generating and assessing evidence for nursing practice. 9. ed. Edition. Philadelphia: Wolters Kluwer Health/Lippincott Williams \& Wilkins; 2012.
Eeva HARJu

TtT, sh, yliopisto-opettaja

Tampereen yliopisto

Yhteiskuntatieteiden tiedekunta, Terveystieteet, Hoitotiede

AnNASTIINA HaKulinen

TtM, tutkija

Tampereen yliopisto

Yhteiskuntatieteiden tiedekunta, Terveystieteet

MarjaAnA Jones

TtM, väitöskirjatutkija

Tampereen yliopisto

Yhteiskuntatieteiden tiedekunta, Terveystieteet

Hanna Ojala

KT, dosentti, yliopistotutkija

Tampereen yliopisto

Yhteiskuntatieteiden tiedekunta

IlkKa Pietilä

FT, dosentti, apulaisprofessori

Helsingin yliopisto

Valtiotieteellinen tiedekunta

Tampereen yliopistollinen sairaala

Tutkimus-, kehitys- ja innovaatiokeskus 